\title{
Historien om antibiotika
}

\begin{abstract}
SAMMENDRAG Utviklingen av kjemiske forbindelser for behandling av infeksjoner kan deles i tre perioder. Først oppdagelsen av alkaloidekstrakter fra kinabark og ipecacuanhabusken på 1600-tallet i Sør-Amerika. Ekstraktene viste seg å ha effekt mot enkelte infeksjoner, særlig malaria (kinin) og amøbedysenteri (emetin). Deretter fulgte utviklingen av syntetiske midler, som vesentlig fant sted i Tyskland og begynte med Paul Ehrlichs (1854-1915) fremstilling av salvarsan i 1909. Den ble kronet med Gerhard Domagks (1895-1964) fremstilling av sulfonamidene i 1930-årene. Til slutt kommer oppdagelsen av antibiotika. Kroneksemplet er utviklingen av penicillin i slutten av 1920-årene - utført av en énmannsforsker som aldri arbeidet i team og aldri i henhold til noe program. Utviklingen av et virksomt preparat skjedde om lag et tiår senere og skyldtes at forskningen nå foregikk i store samarbeidende team, ofte et samarbeid mellom universiteter og ressurssterke industribedrifter. Jakten på nye antibiotika begynte for fullt i siste halvdel av 1940-årene, stort sett med utgangspunkt i jordmikrober. Stadig nye virkestoffer ble oppdaget i det som kan betegnes som antibiotikaens gullalder. De siste tre tiårene har utviklingen av nye typer antibiotika langt på vei stoppet opp, samtidig som mikrobenes resistensutvikling har økt. Denne situasjonen kan kreve nye strategier i behandlingen av infeksjonssykdommer. Hensikten med denne artikkelen er å gi en kort oversikt over historien om antibiotika. Relevante litteraturdatabaser og oppslagsbøker samt egne erfaringer er benyttet.
\end{abstract}

Siden tidenes morgen har infeksjoner hatt den dominerende plassen i menneskets sykdomspanorama. Selv om man ikke kjente årsaken til disse sykdommene, har man alltid forsøkt å bekjempe dem.

Mangfoldet av mikroorganismer er uoverskuelig stort. Allerede de første store mikrobiologer, som Louis Pasteur (1822-1895) og Robert Koch (1843-1910), hadde klare forestillinger om at mikrobene for å overleve i en innbyrdes konkurranse måtte kunne danne livstruende våpen («antibiosis») rettet mot konkurrentene, og at de som overlevde konkurransen på en eller annen måte, hadde klart å nøytralisere motpartens «våpen», altså utviklet «resistens». Disse mekanismene ville, antok de, være sterkest der det mikrobielle mangfoldet var størst, dvs. i jordsmonnet.

Begrepet «antibiotikum» (mot liv) ble først brukt av Selman Waksman (1888-1973) i 1942 (1). Han definerte det som et stoff produsert av mikroorganismer som alt i lave konsentrasjoner dreper eller hemmer veksten av andre mikroorganismer. I de to neste tiårene ble begrepet anvendt $\mathrm{i}$ henhold til definisjonen. Fortsatt anvendes termen, men det inkluderer nå også de mange «antibiotika» som industrien har klart å fremstille semisyntetisk eller syntetisk.

Hensikten med denne artikkelen er å gi leseren en historisk oversikt over menneskenes bruk av kjemiske forbindelser for å bekjempe infeksjoner.

\section{Kunnskapsgrunnlag}

Under utarbeiding av denne artikkelen har vi anvendt søkeord som «History», «Antibiotics», «Antimicrobial agents» og «Anti- microbial resistance» i PubMed, Google Scholar, Wikipedia og internett. Relevante oppslagsbøker, egne erfaringer og kjennskap til faget er også benyttet.

\section{Jakten på «den magiske kulen»} Oppdagelsen av kjemiske forbindelser for behandling av infeksjonssykdommer kan deles i tre perioder (1): fremstillingen av alkaloidekstrakter, utviklingen av syntetiske midler og oppdagelsen av antibiotika.

\section{Alkaloider}

Begynnelsen på den kjemoterapeutiske æra angis til 1600-tallet da kona til den spanske guvernøren i Peru, del Chinchon, ble helbredet for det som sannsynligvis var malaria. Ettter råd fra de innfødte tygde hun barkekstrakt av Cinchona-treet (kinabark oppkalt, om enn feilstavet, etter fruen) (2). Kinabark ble brakt fra Sør-Amerika til Europa senere på 1600-tallet av jesuittmisjonærer og ble her kalt jesuittpulver (2). Ipecacuanhabusken ble importert til Europa fra Brasil i 1658. I 1817 lyktes det å fremstille emetin fra buskens rot. Dette stoffet var virksomt mot amøbedysenteri. Frem til begynnelsen av 1900-tallet var emetin og kinabark de mest anvendte terapeutika mot amøbedysenteri og malaria, og de er fortsatt tilgjengelige i det medisinske armamentarium (2).

\section{Syntetiske forbindelser}

Arbeidet med syntetiske antimikrobielle midler hadde sitt utspring $i$ arbeidet med fargestoffer og foregikk lenge nesten utelukkende i Tyskland. Paul Ehrlich (1854-1915)

\section{Siamak Yazdankhah}

siamak.yazdankhah@legemiddelverket.no

Faggruppe for antibiotika

Statens legemiddelverk

\section{Jørgen Lassen}

Folkehelseinstituttet

Tore Midtvedt

Karolinska Institutet

Claus Ola Solberg

Universitetet i Bergen

> Se lederartikkel side 2445 
(fig 1) innledet denne æraen da han på grunnlag av teorien om «selektiv toksisitet» forsøkte å finne «den magiske kulen». Begrepet «den magiske kulen» har sitt opphav i tysk folklore (3, 4), men Ehrlich definerte det som et middel som kunne angripe patogene mikrober (eller mer generelt patogene celler, herunder også kreftceller) uten å ha noen effekt på de friske vertscellene. Det førte til utviklingen av det arsenholdige salvarsan eller arsfenamin i 1907.

Salvarsan var tiltenkt behandlingen av afrikansk trypanosomiasis (sovesyke). En utstrakt oppfatning på denne tiden var nemlig at bare protozoer, ikke bakterier, kunne kureres med kjemoterapeutika. Salvarsanet viste seg raskt å være aktivt også mot Treponema pallidum, årsaken til syfilis. Midlet erstattet snart kvikksølv $\mathrm{i}$ behandling av syfilis, men bivirkningene viste seg fort å bli for store (2).

Som del av et forskningsprogram for å finne fargestoffer med antimikrobiell effekt syntetiserte Josef Klarer (1898-1953) og Fritz Mietzsch (1896-1858) i 1932 prontosil (sulfonamid-krysoidin) (5). Gerhard Domagk (1895-1964), forskningsdirektør ved I.G. Farbenindustrie i Tyskland, påviste samme høst at dette stoffet i museforsøk hadde antibakteriell virkning mot hemolytiske streptokokker (2). Stoffet hadde ingen effekt in vitro, bare in vivo. Årsaken (antatt av franske forskere allerede i 1935) (2) var at effekten var knyttet til den fargeløse komponenten (sulfanilamid), ikke til fargestoffet krysoidin. Senere fulgte fremstillingen av flere sulfonamider, som ble anvendt mot sykdommer som akutt lungebetennelse (ofte forårsaket av pneumokokker), urinveisinfeksjoner, alvorlige halsbetennelser (hyppigst forårsaket av streptokokker), gonoré, enkelte former for hjernehinnebetennelse og - ikke minst - den fryktede puerperale feberen. Suksessen med sulfonamidene var her så dramatisk at dødeligheten av puerperal sepsis praktisk talt hadde nådd vår tids lave nivå allerede før penicillinet ble introdusert (2).

Innen 1945 hadde farmakologene klart å syntetisere flere tusen forskjellige sulfonamider (6). Selv om bare noen få fikk praktisk anvendelse, anvendes de fortsatt til behandling $i$ både human- og veterinærmedisinen. Domagk fikk for øvrig nobelprisen i fysiologi eller medisin for sitt arbeid i 1939, men måtte si den fra seg etter ordre fra Hitler, som hadde fått nok av nobelpriser etter at Carl von Ossietzky (1889-1938) fikk fredsprisen i 1935 (6). Etter krigen (i 1947) aksepterte Domagk den likevel. Han fikk æren og medaljen, men ikke pengene (6).

Det ble sulfonamidene som endelig endret oppfatningen om at bare protozoer, ikke bakterier, var tilgjengelige for «kjemoterapi». Trolig ble sulfonamidene derfor en avgjørende stimulus for arbeidet med å utvikle antibiotika.

\section{Antibiotika}

Forestillingen om naturlig forekommende «antibiotika» ble formulert av de første pionerene innen mikrobiologi mot slutten av 1800-tallet. Pyocyanase, isolert fra Bacillus pyocyaneus (nå kjent som Pseudomonas aeruginosa) var det første «antibiotikum» som ble introdusert. Også dette er et fargestoff (et blått pigment, opphavet til det «blå pusset» man kan se ved hudinfeksjoner med P. aeruginosa) (2). Substansen, oppdaget i 1888 av Rudolf Emmerich (1852-1914) og Oscar Löw (1844-1941), ble påvist å ha baktericid virkning mot mikrobene som forårsaker difteri, tyfoidfeber, miltbrann og kolera (7). Håpet om at man her endelig hadde funnet en «mirakelkule» blomstret øyeblikkelig opp - men forsvant like fort. Stoffet var for toksisk og ustabilt.

Amerikaneren René Dubos (1901-1982) fremstilte i 1939, for øvrig før penicillinet ble tatt i bruk, tyrotricin fra en bakterie, Bacillus brevis, som han fant i jordprøver. Stoffet besto egentlig av to antibiotika, gramicidin og tyrocidin. Også disse var så toksiske at de bare kunne brukes utvorters i form av salver (8). Dubos presenterte for øvrig sitt funn ved en internasjonal kongress i New York i september 1939 (samtidig med krigsutbruddet) hvor blant andre Alexander Fleming (1881-1955), Howard Florey (1898-1968) og Selman A. Waksman (1888-1973) deltok. Mens Dubos selv snart mistet interessen for antibiotika, fikk hans oppdagelse sannsynligvis stor betydning for Floreys og Waksmans videre satsing på dette området (2).

\section{Penicillin ble -}

nesten - «den magiske kulen»

Historien vil ha det til at penicillinet ble oppdaget ved et rent tilfelle da en dyrkingsskål med stafylokokker som den britiske forskeren Fleming sommeren 1928 hadde glemt å inkubere, var blitt forurenset av en muggsopp. Rundt muggsoppen oppsto en stor bakteriefri sone - soppen hadde åpenbart produsert et stoff som hemmet veksten av bakteriene (9). Dette skal ha vært begynnelsen på den lange veien til penicillinets fremstilling.

Men historien bør modifiseres noe. Riktignok var en rekke tilfeldigheter på Flemings side. Den kanskje viktigste var at skålen ble gjenglemt $\mathrm{i}$ en kjølig periode med temperaturer $<20^{\circ} \mathrm{C}$ (som tillot soppen å vokse mens stafylokokken ble liggende i dvale), som deretter ble avløst av varmere sommerdager (som hemmet soppveksten, men lot stafylokokken vokse - med unntak av der hvor den møtte sop-

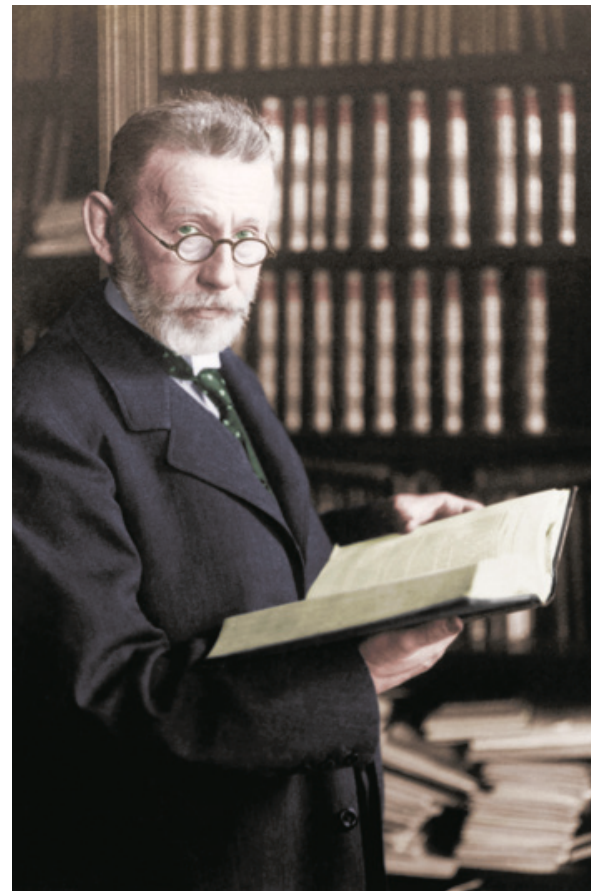

Figur 1 Paul Ehrlich (1854-1915) oppdaget salvarsan, en arsenikkholdig substans som ble brukt mot syfilis. Foto: akg-images/NTB scanpix

pens toksiner) (2). Hvis været ikke hadde skiftet fra kaldt til varmt i denne perioden, ville penicillinet neppe blitt oppdaget den gang av Fleming.

Fleming var for øvrig ikke den første som oppdaget muggsoppens antibakterielle virkning. Det kan mange ha gjort. Kjent er at Joseph Lister (1827-1912) («antiseptikkens far») i 1871 undersøkte det fenomenet at urin som var forurenset med muggsopp, ikke ga vekst av bakterier. I 1874 skal William Roberts (1830-99) ha observert at kulturer med Penicillium glaucum sjelden ble bakterielt kontaminert, og i 1897 anførte Ernest Duchesne (1874-1912) i sitt doktorarbeid at Escherichia coli ble eliminert av den samme soppen. Han viste også at $P$. glaucum i dyreforsøk kunne beskytte mot tyfoidfeber og anbefalte videre fors $ø \mathrm{k}$ på grunnlag av disse observasjonene, men rakk ikke selv å utføre slike før han døde av tuberkulose (10).

Derimot er det nok ikke helt tilfeldig at Fleming, i motsetning til de fleste som må ha observert fenomenet, trakk de riktige konklusjonene da han gjenoppdaget soppens effekt. Han hadde på grunn av erfaring med infeksjoner under den første verdenskrig allerede i en tiårsperiode vært på jakt etter midler med antibakteriell effekt. I 1922 beskrev han således at lysozym, isolert fra tårevæske, hadde en slik effekt (11). Han var altså mentalt forberedt, ikke bare på en slik observasjon, men også på den eventuelle betydningen den kunne få. 


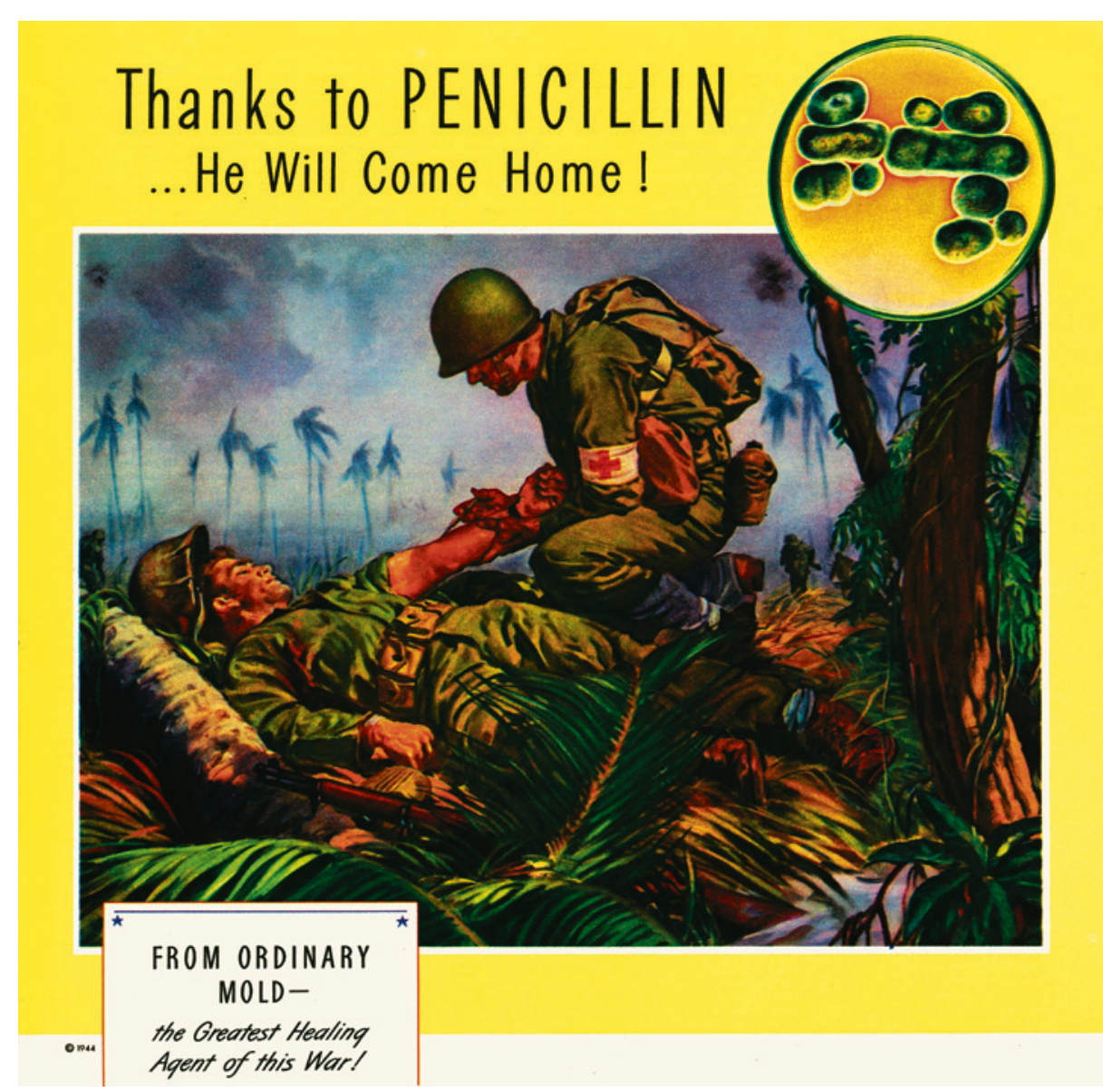

Figur 2 Reklameplakat for penicillin fra den annen verdenskrig (1944). Foto: Image Courtesy of The Advertising Archive

Fleming publiserte observasjonen i 1929 (8) og fortsatte enda et par år arbeidet med penicillin. Men om han var aldri så entusiastisk og aldri i tvil om penicillinets potensial som terapeutikum, klarte han selv aldri å rense eller produsere tilstrekkelige kvanta med penicillinekstrakt for praktiske formål.

En av hans tidligere studenter, Cecil Paine (1905-1994), skal ha vært den første som påviste penicillinets medisinske virkning da han med hell behandlet to pasienter med øyeinfeksjoner, henholdsvis en pneumokokkinfeksjon etter en skade og en gonoréinfeksjon hos en nyfødt, med råekstrakt av soppen (12). Uten denne behandlingen ville den første mest sannsynlig ha mistet øyet og den andre blitt blind. Paine publiserte ikke denne oppdagelsen (og forsinket dermed sannsynligvis penicillinforskningen med atskillige år) (2), men han skal på et møte i 1932 ha nevnt den for Florey, professor i patologi ved Sheffield University - uten at det skal ha vakt vesentlig interesse (13).

Men seks år senere, i 1938, startet Florey, da ved Oxford, sammen med kjemikeren Ernst Chain (1906-1979), en russisk-tysk jøde som hadde rømt fra Nazi-Tyskland og bodde i England, endelig det «penicillinprogrammet» som skulle føre frem til det man først trodde var den endelige «mirakelkulen». Mens Florey hadde kjennskap til mikrobiologi og klinisk forskning, var Chains styrke å isolere, rense og karakterisere substanser som f.eks. penicillin (2).

I slutten av 1930-årene infiserte Florey og medarbeidere åtte mus med en dødelig dose av Streptococcus spp. Fire av musene fikk injeksjoner med penicillin, mens kontrollgruppen ikke ble behandlet. Etter ti dager var musene i kontrollgruppen døde, mens alle i testgruppen overlevde. Det oppsiktsvekkende resultatet ble publisert i det prestisjetunge tidsskriftet Lancet $\mathrm{i}$ august 1940 (14). Fleming, som på dette tidspunktet hadde gitt opp arbeidet med penicillin, ville uten Florey og hans team i dag sannsynligvis ha hørt til de mange «glemte» som nådde nesten, men ikke helt frem.

\section{Penicillin i behandling av infeksjoner}

Den første dokumenterte anvendelsen av sted i 1941 i England (15). En 43 år gammel politimann med livstruende sykdom var døden nær pga. septikemi og fikk penicillin penicillin i behandlingen av et menneske fant intramuskulært hver tredje time i fem dager. Etter 24 timer var han bedre, den fjerde dagen gikk feberen ned, og han begynte å spise igjen. Den femte dagen var det slutt på renset penicillin, pasientens tilstand ble igjen dårligere, og han døde. Til tross for hans død var det likevel klart at penicillin hadde hatt virkning på infeksjonen.

I 1941 ble den store utfordringen for Florey å finne farmasøytiske firmaer som kunne investere i «mirakelmedisinen». Veien gikk til de store farmasøytiske bedriftene i USA, da de europeiske pga. krigen ikke hadde tilgjengelige ressurser (2). Dette trekket bidro til at forskningen skiftet karakter. Fra langt på vei å ha vært dominert av private énmannsforskere, kun avhengige av sine egne (intellektuelle og materielle) ressurser, ble den nå langt mer avhengig av teamarbeid, ofte i store samarbeidsprosjekter mellom universiteter og industri, av og til med publikum som en krevende tredjepart på sidelinjen.

Penicillinet ble raskt et offentlig akseptert «mirakel». To hendelser bidro til det. I desember 1942 ble midlet introdusert for publikum med store overskrifter på førstesidene av alle aviser i USA (16). 29. november 1942 brøt det nemlig ut brann i et danselokale i Boston med 800-1000 gjester. Mer enn 450 brant inne eller omkom i panikken. De skadede ble fraktet til ulike sykehus, mange med livstruende brannsår. Bare 200 overlevde det første døgnet. Men selv denne andelen oversteg forventningene.

Den høye overlevelsen skyldtes ikke minst tre ulike medisinske fremskritt. Det første var introduksjonen av en ny metode for å gi blodplasma som erstatning for væsketapet, det andre var bruken av sulfonamider, som nylig var blitt syntetisert, det tredje et helt nytt preparat som fortsatt var en militær hemmelighet og derfor spesielt attraktivt. På grunn av katastrofens enorme omfang friga regjeringen det hemmelige midlet. 32 liter av «penicillinbuljongen» ble fraktet med militær blålyseskorte 500 kilometer fra New Jersey til The Massachusetts General Hospital. Det var spektakulært nok til å nå på dette tidspunktet fortsatt noe ufortjent avisenes førstesider. Ryktet om en ny mirakelmedisin var født (16).

Den andre hendelsen var selvsagt den annen verdenskrig. Penicillinet var blitt tatt $\mathrm{i}$ bruk av de allierte allerede $\mathrm{i}$ begynnelsen av krigen (4). Krigens gru hadde skapt et enormt behov for gode nyheter. Tiden var overmoden for et «mirakel» - og penicillinet fikk rollen (fig 2). I 1945 ble da også nobelprisen i fysiologi eller medisin tildelt Fleming, Florey og Chain (fig 3). Betydningen av penicillinet ble i de første etterkrigsårene hevet til nærmest mytiske 


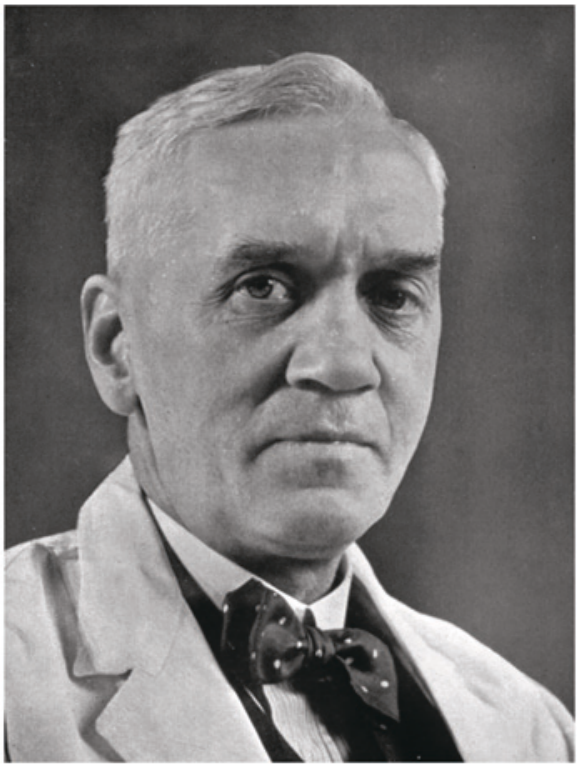

a

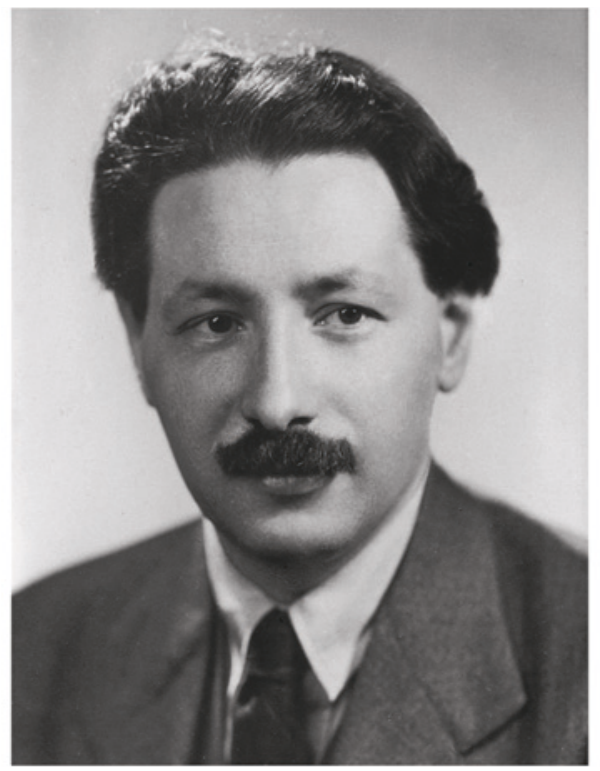

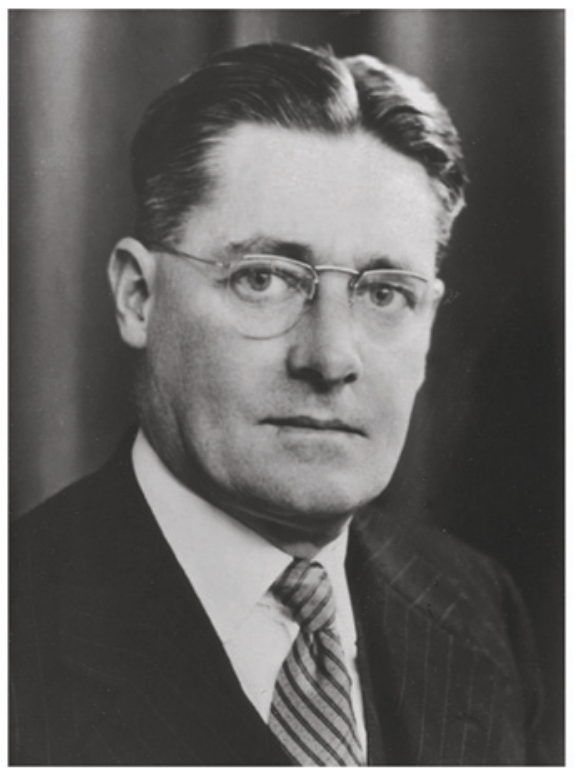

c

Figur 3 / 1945 fikk disse tre nobelprisen i fysiologi eller medisin for oppdagelsen av penicillinet. a) Britiske Alexander Fleming (1881-1955). Foto: The Granger Collection/NTB scanpix. b) Australske Howard Florey (1898-1968). Foto: Heritage/NTB scanpix. c) Russisk-tyske Ernst Chain (1906-79). Foto: Heritage/NTB scanpix

dimensjoner. Det skulle kunne hjelpe mot praktisk talt alle sykdommer, inkludert kreft. Men mirakelets begrensninger viste seg snart. Ikke hjalp det mot forkjølelser og slett ikke mot kreft. Og selv om det virket mot en rekke mikrobearter, særlig mot grampositive bakterier, virket det ikke mot alle, vanligvis ikke mot de fleste gramnegative bakterier. Det viste seg også at enkelte pasienter utviklet alvorlige allergiske reaksjoner mot penicillin.

Store farmasøytiske firmaer begynte å investere stort for å finne nye typer antibiotika. Suksessen med penicillin førte til at flere typer antibiotika ble oppdaget og markedsført, i en periode som kan betegnes som antibiotikaens gullalder.

De første antibiotika mot tuberkulose Mikrobiologene hadde, som nevnt, for lengst erkjent at jord inneholder mikroorganismer som produserer substanser med antimikrobielle egenskaper. I 1943 undersøkte Waksman (fig 4) og hans gruppe, i samarbeid med det farmasøytiske firmaet Merck, 10000 mikrobekulturer for eventuell produksjon av antibakterielle stoffer. Av disse ble ti kulturer ansett som spesielt lovende, og i 1944 kunne endelig Waksmans elev Albert Schatz (1920-2005) etter stor innsats (6) isolere et aminoglykosid fra bakterien Streptomyces griseus. Derfor fikk det navnet streptomycin (17). Dette er det første antibiotikum som viste seg å ha effekt også mot Mycobacterium tuberculosis. Lanseringen av det ble følgelig en verdenssensasjon og Waksman en verdensstjerne. I all viraken som fulgte følte nok
Schatz, som hadde stått for brorparten av blodslitet bak oppdagelsen, at han ble vel mye tilsidesatt. Ikke minst mente han at han hadde fortjente å dele nobelprisen da Waksman fikk denne i 1952 (6).

Waksman mente også selv at han ikke burde fått prisen alene. Han ville ikke delt den med Schatz, men med dansk-svenske Jørgen Lehmann (1898-1989), som er oppdageren av - eller i dette tilfellet rettere oppfinneren av - paraaminosalisylsyre (PAS). Lehmann var lege og biokjemiker, med spesiell interesse for enzymer. På grunnlag av det som var kjent om tuberkelbakteriens metabolisme, dannet han en hypotese om at salisylsyreliknende substanser, og spesielt 4-aminosalisylsyre (PAS), måtte ha effekt mot denne mikroben

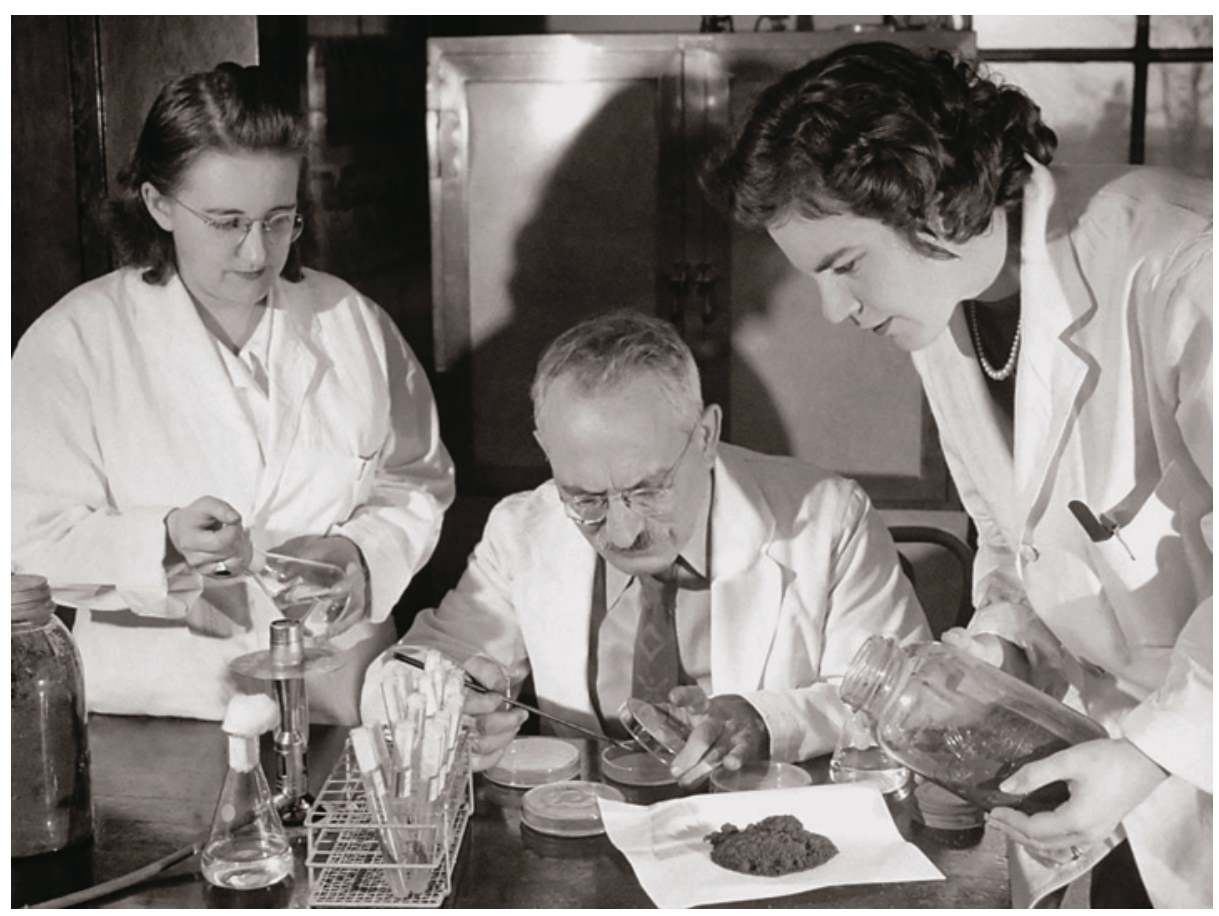

Figur 4 Amerikaneren Selman Waksman (1888-1973) oppdaget streptomycin som det første antibiotikum til behandling av tuberkulose. Han fikk nobelprisen i fysiologi eller medisin i 1952. () National Cancer Institute/ Science Faction/Corbis/NTB scanpix 
(6). Uten ett eneste eksperiment resonnerte han seg altså frem til den korrekte effekten - og fikk deretter det svenske firmaet Ferrosan til å syntetisere medikamentet.

Det ble mer komplisert enn de hadde trodd, men i 1944 ble de første pasientene forsøksvis behandlet, og i 1946 ble preparatet formelt lansert (6). Dette skjedde nesten samtidig med at streptomycin allerede så ut til å kunne bli en skuffelse på grunn av resistensutvikling (6). I motsetning til streptomycin ble imidlertid paraaminosalisylsyre til å begynne med ikke mottatt med jubel. Det ble tvert imot delvis motarbeidet, særlig i Skandinavia (6). Muligens spilte faglig sjalusi en rolle. Nobelprisen, som Waksman alt hadde forskuttert for Lehmann, fikk han i alle fall ikke (6).

Isoniazid og rifampicin var de andre antituberkulosemidlene som kom på markedet, i henholdsvis 1952 og 1963. Allerede i 1912 ble isoniazid syntetisert ved det tyske universitet i Praha (18), uten at man var klar over dets store potensial for behandling av tuberkulose. 40 år senere fant forskere ved Hoffmann-La Roche og E.R. Squibb \& Sons i USA og Bayer i Vest Tyskland samtidig og uavhengig av hverandre at isoniazid også var effektivt mot tuberkelbakterien $(2,6)$. Det ble fort klart at kombinasjonsbehandling med streptomycin, paraaminosalisylsyre og isoniazid bidro til å redusere resistensutvikling mot hvert enkelte preparat.

I 1957, mer enn ti år etter at Schatz oppdaget streptomycin fra en Streptomycesart, oppdaget to italienske forskere, Piero Sensi (f. 1920) og Maria Theresa Timbal (1925-1969) ved det farmasøytiske firmaet Lepetit i Milano en ny bakterie, Streptomyces mediteranei, som produserte en ny klasse antibiotika: rifamycin B. I 1963 ble rifampicin, et semisyntetisk produkt av en modifisert form av rifamycin B, markedsført av det farmasøytiske firmaet CIBA (6).

\section{Kloramfenikol,}

\section{det første bredspektrede antibiotikum}

Jakten på nye antibiotika, som startet for fullt i siste halvdel av 1940-årene, tok stort sett utgangspunkt i jordmikrober. Mikrobiologen Paul Burkholder (1903-72) ved Yale-universitetet undersøkte mikroorganismer isolert fra jord fra ulike deler av verden. Sommeren 1947 mottok han en mikrobe fra Caracas i Venezuela som han kunne påvise produserte substanser som hemmet veksten av både grampositive og gramnegative bakterier (2). Mikrobene ble sendt til firmaet Park Davies for ytterligere undersøkelser.

Den aktuelle mikroben ble senere benevnt Streptomyces venezuelae, etter sitt opphavsland, mens substansen selv ble benevnt klormycetin - senere omdøpt til kloramfenikol
(19). Den første kliniske studien ble utført i La Paz i Bolivia i forbindelse med en flekktyfusepidemi. Park Davies sendte det de hadde av det nye stoffet kloramfenikol. 40 av 50 pasienter som ikke fikk kloramfenikol døde, mens samtlige 22 pasienter som fikk kloramfenikol overlevde (16).

Kloramfenikol hadde den egenskapen at det gikk over i spinalvæsken ved både normale og betente hjernehinner. Det ble derfor raskt tatt $\mathrm{i}$ bruk til behandling av hjernehinnebetennelse, også i nyfødtperioden. I 1950og 60-årene var det vanlig mange steder, særlig i USA, å gi nyfødte antibiotikaprofylakse i noen dager etter fødselen, og kloramfenikol kom raskt i bruk også på denne indikasjonen (20). Etter hvert dukket det opp flere og flere tilfeller av et nytt syndrom «the grey baby syndrome». Barna ble cyanotiske - og mange døde (20). Årsaken viste seg å være bruken av kloramfenikol, som nyfødte har redusert evne til å eliminere. Barna ble kort og godt forgiftet (21).

I løpet av 1950-årene kom det en rekke artikler (20) om alvorlig beinmargsdepresjon etter bruk av kloramfenikol, og midlet fikk mange steder et dårlig rykte, noe som førte til sterkt redusert bruk. De fleste beinmargsdepresjonene viste seg å være reversible, og alvorlig aplastisk anemi ved bruk av kloramfenikol hører heldigvis til sjeldenhetene. Det er nå for lengst slått fast at med adekvat dosering kan midlet gis til pasienter i alle aldersgrupper (20). Medikamentet er billig og har betydelig bredspektret antibakteriell aktivitet. Det brukes fortsatt i stor grad i mange utviklingsland, både mot diaré, lungebetennelse og hjernehinnebetennelse.

\section{Tetrasykliner}

På samme tid som Burkholder oppdaget kloramfenikol, undersøkte Benjamin Duggar (1872-1956) ved Lederles laboratorier i Pearl River, New York, bakterien Streptomyces aureofaciens, som skilte ut en gulaktig substans med antimikrobielle egenskaper (22). Midlet ble først benevnt aureomycin, men ble senere omdøpt til klortetrasyklin.

Det hadde bred aktivitet mot en rekke bakterier, inkludert intracellulære, var mindre toksisk enn kloramfenikol og hadde fordelen - i likhet med kloramfenikol - at det kunne tas peroralt. På grunn av dets aktivitet mot både grampositive, gramnegative og intracellulære bakterier og lave produksjonskostnader anvendes det fremdeles i betydelig grad, særlig i utviklingsland.

\section{Kefalosporiner, penicillinliknende} antibiotika med bredspektret aktivitet I 1945 oppdaget den italienske hygienikeren Giuseppe Brotsu (1895-1975) antibakteriell aktivitet fra ekstrakter produsert av sopp som han hadde isolert fra et kloakk- utløp ved kysten av Sardinia. Soppen fikk senere navnet Cephalosporium acremonium (16).

Det tok lang tid før han klarte å rense aktive substanser fra soppen, som han sendte til Florey og hans kolleger i Oxford (2). Det ble påvist flere stabile derivater med et bredt antibakterielt spekter - herunder derivatene kefalotin og kefaloridin. De ble introdusert på markedet i 1964. I dag finnes det fem ulike «generasjoner» av kefalosporiner på markedet.

\section{Andre $\beta$-laktamer}

$\beta$-laktamantibiotika omfatter mange forskjellige derivater, herunder penicilliner, kefalosporiner, karbapenemer og monobaktamer (17). Penicillinene var i utgangspunktet særlig effektive mot aerobe grampositive bakterier som stafylokokker og streptokokker. Da $S$. aureus-isolater ble resistente mot benzylpenicillin fordi de produserte penicillinase, ble meticillin, som er penicillinaseresistent, fremstilt (i 1960) (17).

I tillegg ble det også fremstilt nye $\beta$-laktamer som hadde et annet eller bredere virkningsspekter enn det opprinnelige penicillinet. Ampicillin (1961) (17) og amoksicillin (1971) (17) virker således mot både grampositive og gramnegative bakterier, piperacillin (1976) (17) virker mot selv den ellers så resistente Pseudomonas aeruginosa. Karbapenemer (1980) (17) er aktive mot grampositive og gramnegative aerobe bakterier. Monobaktamer (1980) (17) er klassen av $\beta$-laktamer som utelukkende er aktive mot gramnegative bakterier (17).

\section{Andre antibiotika}

Suksessene med sulfonamider, penicilliner, kefalosporiner, streptomycin, kloramfenikol og klortetrasyklin førte til fortsatt stor satsing fra farmasøytisk industri og ledet frem til oppdagelsene av neomycin (1949) (23), erytromycin (1952), kanamycin (1957) (23), vankomycin (1956) (23), linkomycin (1962) (23), fusidinsyre (1962) (23) og gentamicin (1963) (23), alle fra jordmikroorganismer (23). Bacitracin ble oppdaget i 1943, oppkalt etter en kultur av Bacillus isolert fra en sju år gammel pasient (1943) (24). Det syntetiske antimikrobielle midlet nalidixin ble utviklet i 1962 (25) og trimetoprim i 1968 (26).

Fremstillingen av de fleste klassene av antibiotika fortsatte ved å syntetisere antibiotika med bredere antibakterielle spektra og høyere aktivitet (2).

\section{Utviklingen stopper opp}

Perioden som betegnes antibiotikas gullalder, opphørte i midten 1960-årene (27), og etter 1987 er det ikke oppdaget noe antibiotikum med nye virkningsmekanismer 
(28). Nesten alle antibiotika som anvendes i dag, tilhører klasser som ble oppdaget før 1970 (28). Legemiddelindustrien har nemlig i lengre tid prioritert andre medikamenter, ikke bare fordi antibiotika karakteristisk nok gis i korte kurer og dermed gir mindre økonomisk avkastning enn midler til langvarig behandling, men også fordi mikrobenes uunngåelige resistensutvikling gjør det vanskelig å forutsi hvilke antimikrobielle virkningsmekanismer det bør fokuseres på (27).

Videre er også endring av utviklingsmetoder med på å forklare den nåværende situasjon med manglende fremstilling av nye antibiotika. I 1990-årene gikk man nemlig over til en genbasert utviklingsstrategi, som ikke har vært vellykket (27). Dertil kommer at hvert nytt antibiotikum er blitt møtt med en tilsvarende resistensutvikling hos mikrobene (29). Endelig førte utviklingen av stadig nye antibiotika i de første tiårene etter den annen verdenskrig til at resistensproblemene i stor grad ble feid under teppet. Kombinasjonen av økende antibiotikaresistens og manglende utvikling av nye typer antibiotika skaper et fremtidsscenario det vil kreve et globalt krafttak for å motarbeide (27).

\section{Konklusjon}

Fremstillingen av antimikrobielle midler i perioden 1920-60 er som et eventyr i kampen mot infeksjonssykdommene de tilstandene som krevde flest menneskeliv. Oppdagelsen av antibiotika er trolig en av medisinens største suksesshistorier. At resistensutviklingen nå skjer i et raskere tempo enn antibiotikautviklingen, er et tankekors. Det vil raskt kunne komme til å kreve nye strategier i behandlingen av infeksjonssykdommer.

\section{Siamak Yazdankhah (f. 1958)}

er ph.d. og seniorrådgiver. Han har vært med på å avgjøre manusets innhold og fremstilling. Forfatter har fylt ut ICMJE-skjemaet og oppgir ingen interessekonflikter.

\section{Jørgen Lassen (f. 1940)}

er spesialist i medisinsk mikrobiologi og tidligere avdelingsoverlege ved Folkehelseinstituttet. Han har vært med på å avgjøre manusets innhold og fremstilling.

Forfatter har fylt ut ICMJE-skjemaet og oppgir ingen interessekonflikter.

\section{Tore Midtvedt (f. 1934)}

er spesialist i medisinsk mikrobiologi og professor emeritus i medisinsk mikrobiell økologi. Han har vært med på å avgjøre manusets innhold og fremstilling.

Forfatter har fylt ut ICMJE-skjemaet og oppgir ingen interessekonflikter.

\section{Claus Ola Solberg (f. 1931)}

er spesialist $\mathrm{i}$ indremedisin og infeksjonsmedisin og professor emeritus ved Det medisinskodontologisk fakultetet. Han har vært med på å avgjøre manusets innhold og fremstilling.

Forfatter har fylt ut ICMJE-skjemaet og oppgir ingen interessekonflikter.

\section{Litteratur}

1. Spring M. A brief survey of the history of the antimicrobial agents. Bull N Y Acad Med 1975: 51 : 1013-5.

2. Greenwood D. Antimicrobial drugs. Chronicle of a twentieth century medical triumph. New York: Oxford University Press, 2008.

3. Williams KJ. The introduction of «chemotherapy» using arsphenamine - the first magic bullet. J R Soc Med 2009; 102: 343-8

4. Bud R. Penicillin. Triumph and tragedy. New York: Oxford University Press, 2007.

5. Domagk G. Further progress in chemotherapy of bacterial infections. Nobel-foredrag 12.12.1947. www.nobelprize.org/nobel_prizes/medicine/ laureates/1939/domagk-lecture.html (28.6.2013).

6. Ryan F. The forgotten plague. How the battle against tuberculosis was won - and lost. New York: Little, Brown and Company, 1993.

7. Emmerich R, Löw O. Bakteriolytische Enzyme als Ursache der erworbenen Immunität und die Heilung von Infectionskrankheiten durch dieselben. Zeitschrift für Hygiene 1899; 31: 1-65.

8. Solberg CO. Antibiotika - kjemoterapeutika. Legemidlene som revolusjonerte behandlingen av infeksjonssykdommene. Norges Røde Kors' legebok. Oslo: Hermes forlag, 1977: 219-31.

9. Fleming A. On the antibacterial action of cultures of penicillium, with the special reference to their use in the isolation of $\mathrm{B}$. Influenzae. Br J Exp Pathol 1929; 10: 226-36.

10. Ernest Duchesne. http://en.wikipedia.org/wiki/ Ernest Duchesne. (28.6.2013)
11. Fleming A. On remarkable bacteriolytic element found in tissues and secretions. Proc R Soc Lond B Biol Sci 1921-1922; 93: 306-17.

12. Zaffiri L, Gardner J, Toledo-Pereyra LH. History of antibiotics. From salvarsan to cephalosporins. J Invest Surg 2012; 25: 67-77.

13. Friedman M. Friedland GW. Medicine's ten greatest discoveries. New Haven, CT: Yale University Press 1998: 176.

14. Chain E, Florey HW, Gardner AD et al. Penicillin as a chemotherapeutic agent. Lancet 1940; 236 : $226-8$

15. Abraham EP, Chain E, Fletcher CE et al. Further observation on penicillin. Eur J Clin Pharmacol 1941; 42: 3-9.

16. Levy S. The paradox of antibiotics. How the misuse of antibiotics destroys their curative powers. 2. utg. Cambridge, MA: Perseus publishing, 2001

17. Saga T, Yamaguchi K. History of antimicrobial agents and resistant bacteria. JMAJ 2009; 52 $103-8$.

18. Meyer H, Mally J. On hydrazine derivatives of pyridine carbonic acids. Monatshefte Chemie verwandte Teile anderer Wissenschaften 1912; 33 $393-414$

19. Dowling HF. The history of the broad-spectrum antibiotics. I: Welchb H, Marti-lbañ F, red. Antibiotica Annual. New York: Medical Encyclopedia, 1958-59: $39-44$

20. Feder HM Jr. Chloramphenicol: what we have learned in the last decade. South Med J 1986; 79 : 1129-34

21. Mulhall A, de Louvois J, Hurley R. Chloramphenicol toxicity in neonates: its incidence and prevention. Br Med J (Clin Res Ed) 1983; 287: 1424-7.

22. Duggar BM. Aureomycin; a product of the continuing search for new antibiotics. Ann N Y Acad Sci 1948; 51: 177-81.

23. Chopra I, Greenwood D. Antibacterial agents: basis of action. Encyclopedia of Science. Hoboken. NJ: John Wiley, 2001

24. Johnson BA, Anker H, Meleney FL. Bacitracin: a new antibiotic produced by a member of the $B$. subtilis group. Science 1945; 102: 376-7.

25. Mah FS. New antibiotics for bacterial infections. Ophthalmol Clin North Am 2003; 16: 11-27.

26. Darrell JH, Garrod LP, Waterworth PM. Trimethoprim: laboratory and clinical studies. J Clin Pathol 1968; 21: 202-9.

27. Livermore DM. Discovery research: the scientific challenge of finding new antibiotics. J Antimicrob Chemother 2011; 66: 1941-4.

28. Cars 0. Det krävs politiska initiativ för ny antibiotika. Svenska Dagbladet 25.1.2013.

29. Unemo M, Shafer WM. Antibiotic resistance in Neisseria gonorrhoeae: origin, evolution, and lessons learned for the future. Ann N Y Acad Sci 2011 1230: E19-28.

Mottatt 31.1. 2013, første revisjon innsendt 7.6. 2013, godkjent 11.10. 2013. Redaktør: Sigurd Høye. 